\title{
EL PLOMO GRECOIBÉRICO DE SAGUNTO Y EL MATIZ EOLIO FOCENSE
}

The Greco-Iberian lead's plate of Sagunto (Valencia) has appeared almost 200 kilometres away from the rest of this set of writings centered in the provinces of Alicante and Murcia. In it we can find the sequences -aisi, -oisi, which are absent from all Iberian lexical repertoire. That is why, based on the evidence of the Aeolism in the lead letter of Ampurias (Emporion I), it is highly probable that the natives adapted, in this particular case, a commercial treaty, their language both to the alphabet and to certain Phokaian Aeolic endings so that it could be read by the Greeks.

Las pruebas epigráficas del impacto de la colonización focense del lejano Occidente van apareciendo en estas últimas fechas con una cadencia de intensidad inusitada. En apenas seis años han sido publicados dos plomos jónicos: el plomo griego - hay otro ibérico- procedente de Ampurias ' ${ }^{\text {, un magnífico }}$ ejemplo de carta comercial y el correspondiente plomo de Pech Maho, del departamento de Aude, en el Languedoc francés ${ }^{2}$, también de carácter comercial, cuyos actores mercantiles son también emporitanos y los testigos (como, acaso sus lugares de origen) indígenas. Este mismo plomo presenta en su otra cara signario y lengua etrusca. Más recientemente ha aparecido otro breve y mutilado plomo griego en Ampurias ${ }^{2}$ bis.

\footnotetext{
1 F. Sanmartí-Greco y R. A. Santiago, «Une lettre grecque sur plomb trouvée à Emporion», $Z P E 68,1987$, p. 119 ss., y «Notes aditionnelles sur la lettre sur plomb d'Emporion", $Z P E 72,1988$, p. 100 ss.; R. A. Santiago, "Sobre una carta griega en plomo, hallada en Ampurias», Actas VII CEEC, vol. III, Madrid 1989, p. 307 ss., y "Encore une fois sur la lettre sur plomb d'Emporion: (1985)", ZPE 80, 1990, p. 72 ss.; R. A. Santiago y F. Sanmartí, "Empuries, passat ifutur: quan el plom parla», L'Escalenc, 1988, p. 1 ss. = Revista de Catalunya 2, nov. 1987.

${ }^{2}$ M. Lejeune, J. Pouilloux y J. Solier, «Etrusque et ionien archaiques sur un plomb de Pech Maho (Aude), Revue Archéologique de Narbonnaise 21, 1988, p. 19 ss.; M. Lejeune y J. Pouilloux, "Une transaction commerciale ionienne au veme. siècle à Pech Maho", Comptes Rendues de l'Academie des Inscriptions et Belles-Lettres, Séances de l'anneé 1988, Paris, p. 526 ss.; Pouilloux, Scienze dell'Antichità 2, 1988, p. 535 ss.

2 bis F. Sanmartí y R. A. Santiago, "Une nouvelle plaquette de plomb trouvée à Emporion", $Z P E 77,1989$, pp. 36-38.
} 
El carácter comercial de uno y otro documento permiten replantear la cuestión del comercio emporitano y del estímulo de este contacto para los pueblos ibéricos. Esta mera constatación es, en sí misma, una novedad, pues hace pocos años la actitud escéptica ante las fuentes literarias referentes al comercio focense con los iberos eran doctrina profesa en los centros de investigación, pero - paradójicamente - era más desdeñosa la actitud de los historiadores que trabajan sobre textos escritos ${ }^{3}$ que la de los arqueó$\log 0{ }^{4}$.

Paralelamente a estos hallazgos se ha producido también el de un par de plomos grecoibéricos, el de Coimbra del Barranco Ancho, de Jumilla (Murcia) ${ }^{5}$ y el de Sagunto ${ }^{6}$, del que nos ocupamos ahora. El documento murciano, según la cerámica a él asociada en el poblado donde se halló, data del siglo IV sin poder determinarse más su cronología ${ }^{7}$. Sus trazos escriturarios son bastante descuidados y su paleografia, similar en muchos aspectos al del Cigarralejo, revela que tiene que datarse en un momento más reciente que el que nos ocupará a partir de ahora.

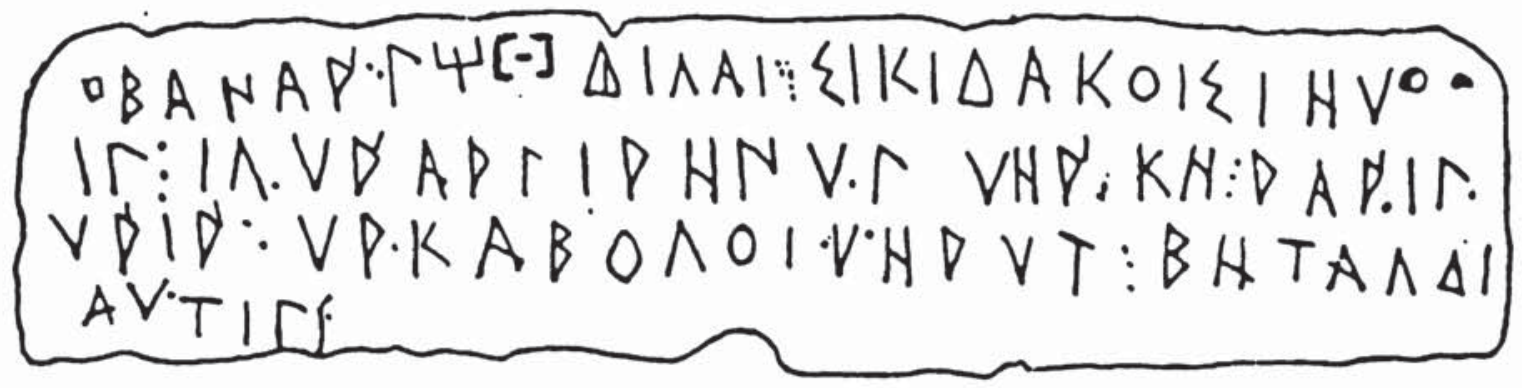

FiguRA 1: Plomo grecoibérico de Sagunto. Escala 1:1.

${ }^{3}$ Hasta negar de plano incluso las referencias literarias sobre la presencia focea en el Levante español como J. P. Morel, «L'expansion phocéenne en Occident: dix années de recherches», $B C H$ 99, 1975, p. 853 ss.; F. J. Fernández Nieto en VV.AA., Historia de España Antigua, I Madrid, Cátedra, 1980, p. 561: sólo alcanzaría el comercio emporitano hasta el Ebro; 571: los bronces griegos proceden principalmente del comercio púnico, etc.

${ }^{4}$ Una posición mucho más favorable ha sido, en esos mismos años la de A. Blanco, «El toro ibérico", Homenaje a $C$. de Mergelina, Murcia 1961, p. 163 ss., que mantuvo la influencia focense sobre la plástica animal ibérica en piedra con argumentos arqueológicos. $\mathrm{Y}$ en general de cuantos se ocuparon de la epigrafía grecoibérica, cf. J. Maluquer, $L a$ epigrafia prelatina de la Península Ibérica, Barcelona 1986, p. 89 ss.

A. M. ${ }^{\text {a }}$ Muñoz Amilibia, «Plomo ibérico en escritura griega de Coimbra del Barranco Ancho (Jumilla, Murcia)», Verdolay 2, 1991, p. 97 ss.

6 D. Fletcher, L. Silgo y L. Pérez Vilatela, «Plomo ibérico en escritura jónica, procedente de Sagunto", I y II, Arse 26, 1992, pp. 1 ss. y 17 ss.

7 Muñoz, o. c. en n. 5, p. 98. 


\section{BANAŔGTI[-] DUILAISI KIDAKOISI EU \\ IG: ILURARGIRENUG UERKE: RAŔIG \\ UR'IŔ URKABOLOI UERUT: BETALDI}

\section{AUTIGI}

Procede de un poblado ibérico de las cercanías de Sagunto. Su soporte físico es una planchita de plomo rectangular, algo roma por sus extremos angulares, de $122 \mathrm{~mm}$ de longitud por $25 \mathrm{~mm}$ de ancho, con un grosor de apenas $1 \mathrm{~mm}$. En otro lugar, hemos procedido al estudio de sus particularidades epigráficas, paleográficas y sus paralelos lingüísticos ibéricos ${ }^{8}$. El hallazgo no procede de excavación.

La planchuela presenta en sus dos extremos superiores sendos orificios de los que quedaría suspendida para hacerse visible en algún lugar público. La lámina se deterioró ligeramente al ser desenrrollada en frío, pero la lectura es clara.

\section{Paleografia y epigrafia}

El alfabeto jónico de este plomito es bastante coherente con los de la Serreta $^{9}$ o El Cigarralejo ${ }^{10}$ este último de escritura más descuidada- y otros textos grecoibéricos menores procedentes del sudeste, pero en conjunto, pese a su brevedad, puede observarse una mayor fidelidad paleográfica a los modelos jónicos: el travesaño de la alfa es más rectilíneo, más uniformemente horizontal que en los citados plomos; la beta en cambio resulta menos fiel, no mantiene los lóbulos curvos, a diferencia de los plomos focenses, siendo en cambio de tipo similar a la mayoría de las grecoibéricas, casi siempre angulosas, como los del Cigarralejo y Jumilla, pero también el grande de la Serreta (Serreta I). En cambio, en el plomo de Elna la beta mantiene los lóbulos curvos (infra).

La gamma de las inscripciones focenses suele tener forma de ángulo recto, aunque en la Grecia arcaica es muy abundante la que se dobla en ángulo agudo. Así son la mayoría de las grecoibéricas. El plomo mayor de La Serreta de Alcoy las presenta más rectilíneas que el del Cigarralejo y éste que nos ocupa relativamente más que cualquiera de los anteriores.

${ }^{8}$ Ofrezco la mía, ligeramente divergente de la de Fletcher y Silgo, Arse 25, passim.

9 R. Visedo, Excavaciones en el Monte "La Serreta», próximo a Alcoy (Alicante), 192122, MJSEA núm. 45, Madrid, 1922, p. 12 y lám. XII; M. Gómez Moreno, Misceláneas. Primera serie. la Antigüedad, Madrid, 1949 (1922), p. 219 ss.; J. Untermann, Monumenta Linguarum Nispanicarum (MLH), IiI 2, Wiesbaden 1990, G.1.1.

${ }_{10}$ E. Cuadrado, «El Plomo con inscripción ibérica de El Cigarralejo (Murcia)», Cuadernos de Historia Primitiva (CHP) 1, 1950, n. 7 ss.; Untermann MLH G.13.1. 
La delta sigue con bastante fidelidad los modelos jónicos, presentándose además en el primer renglón una /du/ ibérica. El travesaño a modo de bisectriz del primer signo deltiforme no constituye una grieta, ni un deterioro zonal: es efectivamente un grafema ibérico. A esta conclusión coadyuva además el que el signo anterior sea también ibérico, no griego, concretamente una / $\mathrm{ti} /$. Estos dos son los únicos signos ibéricos del texto, que aparecen juntos a principio del mismo, como si el escriba, acostumbrado al signario ibérico, se hubiese despistado al redactar el texto en un signario al que no estaba habituado. Algo similar le habría acontecido al acometer ese amago de signo que se observa tras el duodécimo de la primera línea, en lo que parece una /i/ ibérica abortada, pero aquí se habría apercibido a tiempo y no lo habría concluido: téngase en cuenta que el signo anterior es precisamente una iota, cuyo grafema al escriba ibérico le resultaba muy diferente, pues él lo usaba habitualmente para anotar /ba/.

La eta está bien representada: su grafema fue el que los iberos escogieron para anotar/e/ independientemente de su cantidad, en el signario grecoibérico. Es también más fiel al paradigma focense, pues mantiene los trazos rectilíneos, a diferencia de otros documentos grecoibéricos, donde los dos trazos verticales se curvan a la derecha, sobre todo en los plomos de El Cigarralejo y Coimbra del Barranco Ancho (Jumilla). La forma abierta de eta está documentada desde el siglo VII en Teos y desde el VI en Quíos, en la Jonia septentrional ", un territorio que nos interesa especialmente como cuna remota de los tipos escriturarios grecoibéricos. Por esa razón no hay en este sistema etas cerradas. Desde el principio aceptan la forma que tendrá más futuro.

Sobre la iota, aparte de lo adelantado, sólo cabe resaltar la forma sinuosa de la última, que lo es también de todo el texto, en la cuarta línea. Las demás son completamente fieles a los modelos focenses.

También la kappa mantiene su carácter helénico: la primera de las que aparecen -en el primer renglón - no presenta contacto entre la dorsal de la letra y las dos ramas que siguen un ductus continuo, aun así se aproximan bastante. Las otras presentan contacto entre el trazo vertical y las ramificaciones. El primer tipo de kappa es similar a varias del plomo de Ampurias, que alterna con el segundo, que domina en Pech Maho. La lambda presenta ambos trazos de igual tamaño, replicando bien a su paradigma focense. A veces, las otras inscripciones grecoibéricas presentan disimetrías que aquí no se dan.

La ny aparece con una disimetría característica del arcaísmo griego: el trazo vertical de la izquierda es más corto que el de la derecha, en consonancia con

$"$ L. H. Jeffery, The local scripts of the archaic Greece, Oxford 1961, p. 391 ss., Lám. 63 ss. 
los modelos focenses de Pech Maho y Ampurias o la inscripción de la estatua de Aiakes del Heraión de Samos ${ }^{12}$. El plomo grecoibérico de La Serreta I mantiene esta característica que, sin embargo, ya no está presente en el de $\mathrm{El}$ Cigarralejo y Coimbra del Barranco Ancho, cuya ny tiene igual longitud en su trazo derecho que en su izquierdo, revelando así una cronología más reciente.

La ómicron es excelente réplica de la griega, más que la de cualquier otro texto grecoibérico. Varios ejemplares de este documento son casi perfectas circunferencias, otras más ovoides. Pero en ningún caso aparecen las angulosas tan características de otras inscripciones de este sistema escriturario.

La ausencia de pi es la habitual de todos los epígrafes grecoibéricos, en cambio la rho se descompone en dos signos, la sencilla y la que lleva un signo diacrítico, una especie de tilde sobre el signo. A su vez, tanto la sencilla como la tildada, pueden llevar tallo o no. Parece ser que la diferenciación estriba en el signo diacrítico superior y la variabilidad en poseer tallo o no, no influiría en la lectura del signo, no serviría para diferenciar fonemas. La sensibilidad ibérica hacia los sonidos vibrantes que les condujo a generar dos signos diferentes para sus dos fonemas de esta naturaleza en su propia escritura, les llevó a modificar excepcionalmente un signo del sistema gráfico griego original, lo que resulta verdaderamente insólito en la lógica de este sistema escriturario, con ánimo de expresar dos valores fonéticos diferenciados, alteración que no se produjo con ningún otro grafema griego de este sistema. Una situación nueva se planteó con las labiales, a la llegada de los romanos, cuando los iberos tuvieron que registrar palabras de su lengua - principalmente onomásticos- en el abecedario latino, y procedieron a diferenciar $/ \mathrm{p} / \mathrm{de} / \mathrm{b} /$, lo que hasta entonces no habían hecho, ni en el alfabeto grecoibérico, ni en el semisilabario ibérico, donde los signos que contienen labiales se leen con una vocal detrás y varian según ellas, pero no existe en el signario una característica que identifique cada labial, dental o gutural. Sin embargo, precisamente por el alfabeto grecoibérico sabemos que existían en lengua ibérica los sonidos $/ \mathrm{t} / \mathrm{y}$ $/ d /$ por una parte; /g/ y / $/$ por otra. En cambio ¿cómo es que falta pi en este signario y en cambio se registre /p/ en alfabeto latino, como distinta de /b/ al anotar voces ibéricas? Tal vez por un proceso de adaptación incompleto, como el que condujo a la creación del abecedario latino a partir del alfabeto griego de Cumas, que en principio no se preocupó de adaptar un signo para $/ g /$, valiendo la ce para anotar $/ \mathrm{c} / \mathrm{y} / \mathrm{g} /$ pero que en época ya muy avanzada procedió a utilizar un signo diacrítico en la $\mathrm{C}$ dando $\mathrm{G}$, para anotar $/ \mathrm{g} /$, que sin

12 R. Meiggs y B. Lewis, A Selection of Greek Historical inscriptions to the end of the fifth century, Oxford 1969, p. 16; Jeffery, o. c., p. 341; M. Guarducci, Epigrafia Greca, Roma 1967, p. 259: inscrip. de Aiakes. 
embargo no se difundió con rapidez, pues $\mathrm{C}$ y $\mathrm{G}$ alternaron en las mismas palabras durante mucho tiempo, sobre todo en los epígrafes.

La sigma es de extremos abiertos, como suelen serlo en la epigrafia grecoibérica, de forma más exagerada en general que sus prototipos griegos.

No figura ninguna sampi en el texto. Esto es extraño, porque esta letra jónica arcaica aparece habitualmente en los demás textos grecoibéricos, pero dado que éste es un documento de breve extensión, tampoco podemos considerar esta ausencia como algo significativo respecto a la datación del propio epígrafe. Por otra parte, estima J. de Hoz que el hecho de que el alfabeto grecoibérico mantuviese este signo, que no sobrevivió al arcaísmo griego, no es prueba para determinar la antigüedad de este alfabeto ${ }^{13}$. Sin embargo otros autores han aceptado que su fecha de adaptación corresponde al arcaísmo griego ${ }^{14}$, o al siglo v a. C. ${ }^{15}$, lo que sostiene también de $\mathrm{Hoz}^{16}$.

Menos cursiva que en otros plomos grecoibéricos se nos presenta la tau y, en cambio, mejor réplica de sus modelos focenses en su rectilinealidad.

La ýpsilon, a diferencia de la rho, se presenta sistemáticamente sin tallo, como los modelos jónicos arcaicos, así las dedicatorias de las estatuas de Cheramyes (hacia 570-60) o de Aiakes (c. 500?) según la cronología de Jeffery ${ }^{17}$, por lo que también aquí cabe poner relación un hecho epigráfico con otro. La última ýpsilon sin tallo se documenta en Clazómenas, hacia 475-450. En el resto de la epigrafia grecoibérica también domina la ypsilon sin tallo y ya es sabido que su cronología es posterior, de mediados del siglo iv en los hallazgos que han podido ser datados (El Cigarralejo, Mula; Coimbra del Barranco Ancho, Jumilla) ${ }^{18}$.

El momento de adaptación del alfabeto grecoibérico hubo de ser, pues, anterior a 475-450 a. C. como tope reciente. Este documento ha de ser, pues, anterior a mediados del IV y posterior a los inicios del v, un marco cronológico demasiado amplio, ciertamente.

13 J. de Hoz: "La escritura grecoibérica», Studia Paleohispanica. Actas IV Coloquio sobre lenguas y cultural paleohispánicas, Veleia 2-3, 1987, p. 268.

14 G. Băhr, «Baskish und Iberisch», Eusko-Jakintza, 1948, p. 62; M. Gómez Moreno, «De epigrafia grecoibérica: el plomo de Alcoy», Misceláneas. Primera serie: La Antigüedad, Madrid 1949, p. 228; M. Lejeune, «À propos d'un plomb inscrit d'Elne», Revue des Études Anciennes 62, 1960, p. 72 ss.

15 E. Cuadrado, "El plomo con inscripción ibérica de El Cigarralejo (Murcia)», Cuadernos de Historia Primitiva 1, 1950, p. 36 ss., antes del siglo IV; J. Maluquer, Epigrafia prelatina de la Peninsula Ibérica, Barcelona, 1986, p. 92, hacia 450 a. C.

16 De Hoz, o. c., p. 290, segundo cuarto del siglo V.

17 Jeffery, The local scripts..., p. 341 ss.; Meiggs y Lewis, A Selection..., p. 16.

18 Cuadrado, «El plomo con inscripción ibérica...», p. 36 ss.; Muñoz Amilibia, «Plomo ibérico...", p. 98 ss. 
Un lugar aparte debe hacerse para el plomo "grecoibérico» (?) de Elna, al que difícilmente podemos agrupar con los demás y del que dudamos seriamente que pueda incluirse en el grupo. Su alfabeto no es el mismo, pues incluye $\mathrm{E}, \Theta, \Pi$, que no existen en ninguno de los otros textos grecoibéricos. Se trata de una adaptación diferente, más reciente y autónoma y tal vez a una lengua distinta del ibérico ${ }^{19}$.

La paleografia del mismo, por su parte, indica fechas entre el siglo IV y el II que se corresponden, adicionalmente, con los materiales arqueológicos de Elna: la épsilon tiene forma lunar, la ny presenta el trazo de la derecha hasta la base, como en el texto de El Cigarralejo, la kappa es cursiva y con un bucle en lo alto del respaldo del trazo izquierdo, sin paralelos arcaicos, la ypsilon presenta un muy desarrollado tallo, nuevos rasgos de «modernidad» en comparación con el arcaísmo dominante en la paleografia del documento saguntino, e incluso también con el de El Cigarralejo ${ }^{20}$.

\section{Segmentación}

Las interpunciones en forma de tres puntos uno sobre otro se dan en el arcaísmo griego y latino y en los otros sistemas escrituarios itálicos derivados del alfabeto griego. Estas son las verdaderamente valiosas para separar segmentos, en este caso frases. Este es nuestro primer criterio. Las restantes interpunciones, de un punto o de dos (nunca colocados en vertical pura), no sabemos a qué obedecen. Algunas pueden ser resultado del deterioro del plomo, pero otros están evidentemente trazados intencionadamente.

El segundo criterio será la comparación con palabras y giros ibéricos ya conocidos. Pero este epígrafe presenta palabras nuevas, o que parecen nuevas. Tal vez el vector alfabético en lugar del más habitual signario ibérico, produzca aparentes novedades.

Esta es nuestra propuesta:

Banaŕ g ti[-]duilaisi kidakoisi eu/ig: ilứargiren ug uérke: rárig / ứrír urkaboloi uerut betaldi / autigi.

En otro lugar hemos dado las razones para cada una de estas segmentaciones. Algunas son muy evidentes: Ilurargir-en es un onomástico seguido de la partícula posesiva -en. Urkaboloi es otro onomástico, que Fletcher y Silgo prefieren como Urkabolo para aislar el postfijo -iu, pero que en mi opinión no

19 Lejeune, «À propos...», p. 72, señalaba que se trataba de una adaptación independiente con modalidades diferentes.

${ }^{20}$ Lejeune, "À propos...", p. 65 ss. 
es conveniente, pues $-i u,-u$ en ibérico, tras onomástico, aparecen siempre en número mayor a uno, de forma correlativa ${ }^{21}$.

También son fácilmente aislables Autigi, onomástico, o topónimo en -tigi con abundantes paralelos ${ }^{22}$. Parece razonable no querer prolongar por delante esta palabra añadiendo alguna letra de Betaldi que puede dejarse así tras una segmentación previa.

Tal vez uerut tenga alguna relación con uerke. Ambas palabras comienzan igual y cada una de ellas acaba frase.

\section{Posibles dativos eólicos}

El plomo ibérico de Sagunto incluye posiblemente un par de vocablos en cuyas terminaciones pueden detectarse sendos dativos del plural de temas en -o y en -a, con tratamiento eólico (estos últimos por analogía) ${ }^{23}$.

Evidentemente, la segmentación que demos al texto influye decisivamente en la fijación del mismo. Para esta cuestión el signario grecoibérico se vale, en el caso del plomo de La Serreta I, de tres interpunciones colocadas verticalmente, que en este texto aparecen también. Pero si en el santuario alcoyano estos tres puntos separan palabras, en el documento saguntino separan segmentos o frases. Otras interpunciones repartidas por el texto, incluso en el interior de lo que son, indudablemente, palabras completas como I YYPAPГIPHN, no pueden ser tenidas en cuenta para seccionar palabras. Alguna de estas punciones puede haberse producido fortuitamente.

Los tres puntos serán, pues, aquí, el criterio decisivo para aislar las frases. En la primera aparecen dos signos ibéricos, cuya lectura es respectivamente /ti/ y /du/. El resto del plomo está uniformemente redactado en alfabeto grecoibérico. Pero Fletcher y Silgo proponen leer la última gamma de la primera línea como si fuese una lambda y enlazar este signo y su precedente $\mathrm{I}$, con la primera palabra de la segunda línea, quedando así *Ilurír ${ }^{24}$ vocablo que suena mucho a toponomástico ibérico, vulnerando la triple interpunción.

Esta consideración les lleva de facto a considerar la citada gamma como una «ele» ibérica, pues la lambda grecoibérica es siempre simétrica con ambos brazos de idéntica longitud ${ }^{25}$ hasta una misma línea de base. $Y$ en este texto esta simetría se cumple modélicamente con todas las lambdas. En consecuen-

21 J. Untermann, «La gramática de los plomos ibéricos», Studia Paleohispanica, Veleia 2-3, 1987, p. 41; Pérez Vilatela, "Plomo ibérico...», Arse 26, 1991, p. 36.

${ }^{22}$ Pérez Vilatela, $o . c$., con un listado, p. 43 ss.

${ }^{23}$ P. Chatraine, Morphologie historique du Grec, París, 1947, pp. 36-37; E. Schwyzer, Griechische Grammatik, I, Munich, 1959, p. 559.

24 Fletcher y Silgo, «Plomo ibérico...», p. 3.

25 Pérez Vilatela, «Plomo ibérico...», p. $36 \mathrm{~s}$. 
cia, no podemos aceptar que este signo sea una lambda. En cambio, la «ele» de la escritura ibérica "pura» resulta ser una lambda asimétrica, como las más antiguas del arcaísmo griego, anteriores al establecimiento de los focenses en Occidente. Jeffery señala que en la propia Marsella ya encontramos hacia 500-475 (?) A y $\Lambda$ simétricas ${ }^{26}$ así como en Velia, c. $480{ }^{27}$ y en Lámpsaco A y $\Lambda$ también simétricas, de 450-425 (?) ${ }^{28}$.

La epigrafia griega de la propia Ampurias presenta a fines del siglo VI, A y L simétricas ${ }^{29}$, dato epigráfico corroborado por el plomo emporitano hallado en las excavaciones de $1985^{30}$.

Sólo de detectan signos ibéricos pues, en la primera línea del texto y en el caso de la /ti/ con un valor extralingüístico probablemente.

Pero es también en este renglón donde se localizan los dos dativos eólicos del texto que serian, según nuestra segmentación, la palabra segunda y tercera del texto. Se trata de Duilaisi y Kidakoisi, dos palabras contiguas, en el mismo caso y número constituyendo una misma secuencia, pues. Ninguna de estas palabras es griega, tan sólo sus terminaciones. ¿Podría, en consecuencia, tratarse meramente de una mera homofonía, de una casualidad fonética? No puede ser así por las siguientes razones:

- La secuencia - $\alpha \iota$, -oเø, no se documenta en ningún otro texto ibérico. $\mathrm{Y}$ no se olvide que de esta lengua conocemos ya cerca de tres mil palabras.

- El texto que presentamos está escrito precisamente en caracteres griegos y en una zona donde no ha aparecido ningún otro documento ibérico transcrito en el alfabeto helénico. Es un documento donde la influencia griega es intensamente palpable.

- La aparición de otro eolismo idéntico en un plomo focense occidental, el aparecido en las excavaciones de Emporion en 1985. Y además, precisamente

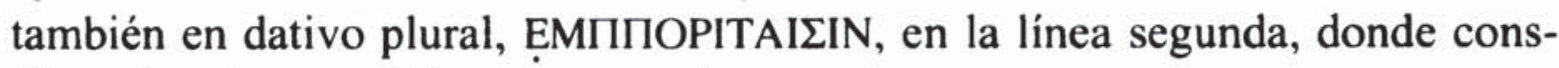
tituye la primera palabra conservada.

De la misma forma restituyen Sanmarti-Greco y Santiago EnIBA [TAIIIN] en la línea segunda ${ }^{31}$.

26 Jeffery, The local Scripts..., lám. 54, 2.

27 C. M. Kraay y M. Hirmer, Greek Coins, Nueva York, s. d., n. 225.

28 Jeffery, láms. 71, 48.

29 M. Almagro Basch, Las inscripciones ampuritanas griegas ibéricas y latinas, Barcelona $1952, n^{\circ} 44$ (p. 54).

${ }^{30}$ E. Sanmarti-Greco y R. A. Santiago, «Une lettre grecque sur plomb trouvée à Emporion», ZPE 68, 1987, p. 119 ss.; R. A. Santiago, «Notes aditionnelles sur la lettre sur plomb d'Emporion», $Z P E 72,1988$, p. 100 ss., "Sobre una carta griega en plomo, hallada en Ampurias", Actas VII Congreso Español de Estudios Clásicos (CEEC), vol. III, Madrid 1989, p. 307 ss., y «Encore une fois sur la lettre sur plomb d'Emporion: 1985», ZPE 80, 1990, p. 72 ss.

31 Sanmarti-Greco y Santiago, "Une lettre...», $Z P E$ 68, 1987, p. 119 s., y "La Lettre grecque d'Emporion et son contexte archéologique», Revue Archéologique de Narbonnaise 21,1989 , p. 12 ss. 
Las dos palabras con desinencias élicas del plomo grecoibérico de Sagunto no son griegas. Son evidentemente indígenas, porque no las tenemos registradas hasta el momento en el repertorio ibérico. Sin embargo, sí contamos con paralelos en el celtibérico. Nos referimos a las Duillae, unas diosas mencionadas en dos epígrafes latinos en dativo plurar Duillis, procedentes de las cercanías de la ciudad de Palencia, con paleografia característica del siglo I d. C. ${ }^{32}$.

Dicen respectivamente:

\author{
1) ANNIVS / ATREVS / CAERRI / AFRICANI./ \\ F(ilius) / DVILLIS / V(otum) S(oluit). L/(ibens). M(erito). \\ 2) $C L$ (audius) LATTU/RUS DUIL/LIS V(otum) $S$ (oluit). L/(ibens)./ M(erito). [E] \\ $\mathrm{X}$ VI(su)
}

Hubo una tercera ara en este hallazgo, que ya Fita, el editor de todas tres, encontró muy deteriorada. No se conserva, pero se sabe que era votiva y contenía una A.

Hay, en fin, una ara anepigráfica encontrada en el mismo lugar con la configuración de dos mujeres, quienes según Schmoll podrían ser la figuración de esas Duillae, tal vez similares a las Matres veneradas por otros celtas ${ }^{33}$.

También YPKABO $\Lambda$ OI podría presentar una desinencia de dativo eólico, o sencillamente griego, dado que la escritura grecoibérica desconoce la omega. Este vocablo es indiscutiblemente ibérico, pero la terminación -oi pudiera ser acaso griega.

Sin embargo no disponemos aquí del mismo margen de seguridad que en las dos palabras aludidas de la primera línea, puesto que la iota pudiera acompañar a la ýpsilon que le sigue, dando -iu, secuencia que se da en ibérico, aunque como ya mencioné casi siempre consecutiva (alternando con -u) ${ }^{34}$, tal como proponen Fletcher y Silgo (supra).

Otro plomo ibérico también procedente de la Punta de Orleyl (Vall de Uxó, Castellón) ${ }^{35}$ presenta numerosas palabras acabadas en -AI o -EAI pero no

32 J. M. Blázquez Martínez, Religiones primitivas de Hispania, I. Fuentes literarias y epigráficas, Roma 1962, p. 67 ss., y Diccionario de religiones prerromanas de Hispania, Madrid 1975, s. u. (p. 90); EE IX n. 296; HAEp. 1-3, n. 400. Además hay un dios Dulouius en las Galias, CIL XII 1279-1280, cf. S. Lambrino, "Le dieu celtique Dulouius», Mélanges Piganiol, III, p. 1353 ss.

${ }_{33}$ U. Schmoll, Die Sprache der vorkeltischen Indogermanen Hispaniens und das keltiberische, Wiesbaden 1959, p. 47; M. L. Albertos, «Nuevas divinidades de la antigua Hispania», Zephyrus 3, 1952, p. 49 s.

34 D. Fletcher et alii, Materiales de la necrópolis ibérica de Orleyl, Valencia 1981, pp. 63,90 , presenta en la segunda línea de un plomo Atilebeiu sin otro /u/ o /iu/ consecutivo, cf. $M L H$ F. 9.5 , p. 385 .

${ }^{35}$ Fletcher, o. c., pp. 97-116 = MLH F. 9.7 = baŕbinkeai ... bototaśeai ... selkeaibartuneai y también anérai, śanibeiŕai, leitaśeai, etc. Esta secuencia se añade a onomásticos bien conocidos, como Bodotas. 
conozco un caso semejante en -OI, salvo la inscripción jónica sobre cerámica de Huelva (v. infra). Esta secuencia -AI, -EAI, es escasa en ibérico en posición final y la segunda en cualquiera.

En consecuencia, cabe deducir que este documento fue redactado por unos iberos que tenían contacto habitual con los griegos y querían que éstos pudiesen acceder a la lectura de unos onomásticos (antropónimos, teónimos y/o topónimos) indígenas, para lo cual redactaron este pequeño texto en caracteres griegos. En la fecha de redacción ya estarían habituados estos iberos saguntinos al signario ibérico estricto y prueba de ello son los deslices hacia la escritura ibérica en la primera línea.

El texto estuvo destinado a colgar de dos orificios superiores que se notan en el calco, y por donde pasaría un cordel. Esta posición suspendida es prueba de que el texto no era una imprecación o un mero recibo, ni siquiera una carta, pues estos documentos, cuando son redactados sobre planchuela de plomo, eran posteriormente enrollados. Pero el destino primario de la presente tablilla era quedar expuesta a la vista del público y de un público, en parte al menos, griego. Por esa razón, el escriba saguntino arregló las desinencias de algunos vocablos indígenas de manera que cobrasen sentido a oídos de los comerciantes focenses: es el caso de Duilaisi y Kidakoisi.

Tal vez el plomo tuviera carácter de tratado comercial y los onomásticos que figuran al final Betaldi y Autigi fuesen nombres de los testigos, o bien Autigi ser un topónimo con el étimo -tigi, muy abundante en el Sur de España.

Más allá de las Columnas de Hércules, en Huelva han ido revelándose a la piqueta del excavador abundantes fragmentos de cerámica griega arcaica, de gran importancia arqueológica. En uno de los fragmentos figura una inscrip-

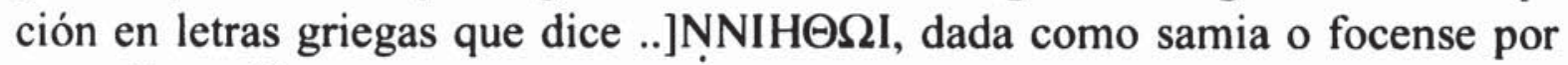
sus editores ${ }^{36}$.

Lo más curioso es que esta palabra o fragmento no ha podido ser relacionada con ningún vocablo griego hasta la fecha. Sin embargo, sí podría ocultar un onomástico indígena *Niethos o menos probable *Anniethos. Para la primera forma tenemos paralelo en el teónimo Neton, dios de los Accitani, según Macrobio ${ }^{37}$, registrado también epigráficamente ${ }^{38}$. Para la segunda, los abundantes Annedius, Annidius, etc., documentados asimismo en la epigrafia latina andaluza ${ }^{39}$.

36 J. Fernández Jurado y R. Olmos, «Una inscripción jonia arcaica en Huelva», Lucentum 4, 1985, p. 107 ss.

${ }_{37}$ Macr. Sat. II, 19, 5.

38 J. M. Blázquez, Religiones primitivas de Hispania, I. Fuentes literarias y epigráficas, Roma 1962, p. 94, s. 224, venerado en Lusitania.

${ }_{39}$ M. L. Albertos, La onomástica personal primitiva de Hispania Tarraconense y Bética, Salamanca 1965 , p. 27, s. u. 
Pero según sus editores el texto debe restituirse mediante paralelos epigráficos arcaicos griegos sobre vasos y quedaría:

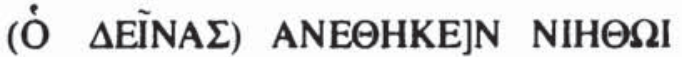

o bien:

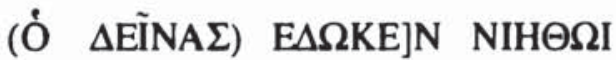

«Me dedico a Nietho» o bien «Me dio...».

Paleográficamente, tenemos aquí una inscripción típicamente jonia con una $\boldsymbol{\Omega}$ de apéndice derecho mucho más horizontal que el izquierdo que prácticamente no existe característica del arcaísmo jonio ${ }^{40}$. Es curioso que Jeffery atribuya a la costumbre de escribir sobre rollos de cuero algunas características de la epigrafia jónica, como ésta ${ }^{41}$ : la naturaleza de la investigación arqueológica sólo permitirá el rescate de los soportes duros de la epigrafia, como el plomo, utilizado también por los jonios en la relación epistolar y transmitiendo a los iberos su uso para este fin.

La theta con cruz inserta es la habitual en los alfabetos arcaicos ${ }^{42}$ y la ny tiene el trazo derecho menos desarrollado que el izquierdo, sin lograr alcanzar la base del izquierdo, como ya hemos visto en la lámina plúmbea que nos ocupa.

Respecto a la inscripción onubense que en su paleografía podría ser samia o focense es indudablemente jónica en cualquiera de los dos casos. Hasta hace poco había cierta tendencia a premiar teóricamente lo samio para fechas arcaicas en lo referente a España, sobre todo a Andalucía, reservándose la conceptuación de focense para fechas posteriores. Ello venía en relación con el viaje de Coleo ${ }^{43}$, pero ya bien atestiguada la paleografia arcaica focense del extremo Occidente, es metodológicamente correcto reivindicar a los focenses.

\section{Eolismos en el plomo de Ampurias}

La inscripción de la lámina de plomo emporitano data de la segunda mitad del siglo VI a. C. y posiblemente, del último cuarto y ha sido publicada por E. Sanmartí-Greco y R. A. Santiago ${ }^{44}$.

Otras peculiaridades del plomo griego hallado en Ampurias pueden considerarse eolismos, como lo hacen sus editores R. A., Santiago y E. San-

40 M. Guarducci, Epigrafia greca I, Roma 1967, p. 260.

41 Jeffery, The local scripts.... p. 327.

42 Jeffery, The local scripts..., p. 29; Guarducci, Epigrafia greca, p. 259.

43 Heródoto IV 152; sobre esta navegación v. A. García y Bellido, Hispania Graeca I, Barcelona 1948, p. 10 ss.; su eventual relación con los fenicios en B. Frayer-Schavenburg, «Kolaios und die westphönizischen Elfenbeine», Madrider Mitteilungen 7, 1966, p. 89 ss.

44 Sanmartí-Greco y Santiago, "La lettre grecque d'Emporion...», RAN 21, p. 12. 


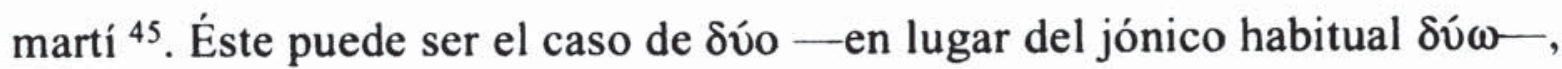
forma que también aparece en varios otros dialectos ${ }^{46}$.

También es eolia la forma wĩ lugar de oior, la forma jónica y precisamente se trata aquí del más corriente de los verbos griegos (y de la mayoría de las lenguas indoeuropeas) y en el tiempo más habitual de la conjugación, el presente. Son escasas, efectivamente, las formas verbales eolias documentadas de este tipo, $\lambda \alpha \mu \beta \omega i ́ \sigma v$ y alguna otra de una inscripción de Quíos, del siglo v.

Ciertamente que el eolio continental tuvo un escaso desarrollo literario, máxime al compararlo con el jonio y jonio-ático. Sólo el lesbio en las islas minorasiáticas presenta, gracias a Safo, un fugaz esplendor literario. En general, el eolio continental o minorasiático está mal documentado: en esto conviene la investigación, pero ¿qué podemos decir de los restos lingüísticos de la Jonia septentrional asiática y concretamente de Focea? ¿Los conocemos tal vez mejor, quitado el caso de Quíos, quien presenta precisamente también eolismos en su epigrafia? Ante este estado de cosas, sigue resultando sensata la heurística propuesta por Langlotz ${ }^{47}$ : intentar conocer la expresión escrita focea, por medio de las inscripciones de sus colonias.

J. Chadwick en carta dirigida a los editores de la carta jónica sobre plomo de Ampurias sostiene que el «focense, como el quiota fue un dialecto mixtificado de algunas formas del lesbio que se dan junto al jónico normal» ${ }^{48}$.

Otras posibles eolismos podrían ser $\pi$ on $\tau$ óov en la línea sexta, adjetivo verbal de $\pi$ oté $\omega$, sin iota, en lo que coincide con el dialecto ático. Si tenemos que elegir entre influencia eólica o ática, no cabe duda de que se trata de la primera.

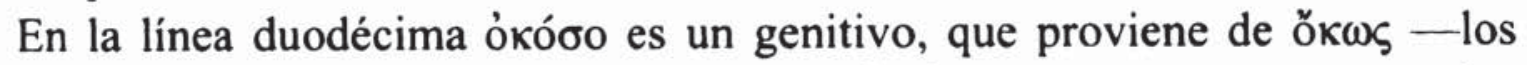
signos diacríticos no figuran, claro está, en el plomo-y es un rasgo arcaico del habla minorasiática, con paso $\mathrm{a}-\mathrm{K}$ - de la labiovelar original, pero que se extiende por la Jonia, Eritras ${ }^{49}$, Egias ${ }^{50}$, Quios ${ }^{51}$, según la epigrafia.

${ }^{45}$ R. A. Santiago y E. Sanmarti-Greco, «Empuries, passat i futur: quan el plom parla» Revista de Catalunya 2, nov. 1987 = L'Escalenc (La Escala), 1988, p. 6 ss.

46 C. D. Buck, "The interrelations of the Greek Dialects», CL. Phil. 2, 1907, p. 241 s.; O. Hoffmann, A. de Brunner y A. Scherer, Historia de la lengua griega (trad. esp.), Madrid 1973, pp. 54, 63 s., 95.

47 E. Langlotz, Die kulturelle und kunstlerische Hellenisierung der Kusten des Mittelmeers durch die Stadt Phokaia, Colonia-Opladen 1966.

48 J. Chadwich apud Santiago y Sanmarti-Greco, "Une lettre...», n. 43.

49 H. Collitz y F. Bechtel, Sammlung der greiechischen Dialekt-Inschriften, IV, Gotinga, 1884-1915 (reimpr. 1973), p. 883, n. 62, 11 = Inschriften von Erythrai 205, 11.

50 E. Schwyzer, Dialectorum Graecorum exempla epigraphica potiora, Hildesheim 1960 (Lipsia 1923), 664, 8.

51 Schwyzer, Dialectorum..., 687. 
Otro rasgo de impronta eólica debe ser la geminación de la pi en 'E su desinencia de dativo plural. Sanmartí-Greco y Santiago dicen que puede tratarse de un rasgo dialectal. Efectivamente, creemos que obedece también a esta influencia eólica, comparando vg. $\kappa \alpha \lambda \lambda v \sigma \mu \alpha \tau \alpha$ de una inscripción de

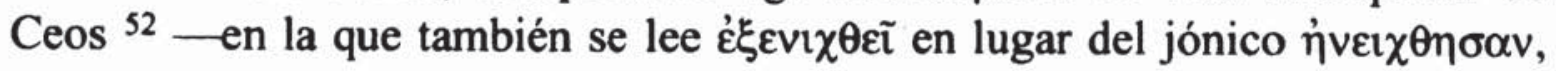
que podría ser asimismo eólica. Otras geminaciones proceden de tratamiento particular de grupos consonánticos como $\sigma v>v v$, documentados en la Cime anatólica o en Quíos: $\Phi \alpha \varepsilon ́ v v \eta \varsigma$, , $\alpha$ $\alpha v \alpha \gamma o ́ \rho \alpha \varsigma, ~ \Phi \alpha v v o \theta \varepsilon ́ \mu ı \varsigma^{53}$, la Dórida, según la prosa de Heródoto de Halicarnaso ${ }^{54}$, — quien mejor nos ha informado sobre el destino de Focea, por otra parte.

Observan con perspicacia los editores que este fenómeno de evolución de la labiovelar se observa en tesalio y arguyen que esta tendencia pudo haberse prolongado en el habla eólica, influyendo en el momento de la colonización sobre los subdialectos jónicos 55 .

También obtiene el eólico geminación consonántica del tratamiento $\rho \sigma, \mathrm{si}$

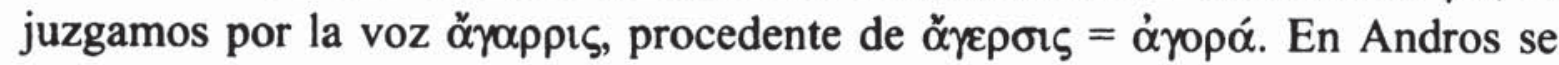
documenta una inscripción con la forma $\varepsilon \mu \mu^{56}$. Por tanto consideramos la geminación de la carta emporitana - no procedente de un tratamiento de grupo consonántico- como otro rasgo eólico.

También debe ser un rasgo de la influencia eolia el recurso a la geminación de que se observa en el plomo de Elna (Rosellón), de lengua indígena y alfabeto griego: se trata de la tercera línea de este fragmentario texto, donde se lee $\triangle I O Y A \Theta \Theta\left[E\right.$ ?, acaso la rotación de una silbante fuerte ${ }^{57}$.

No está nada claro que la lengua de este plomo sea ibérico, pues en él figuran la $p i$ y la theta, dos letras rechazadas por el signario grecoibérico.

52 Schwyzer, 766, 23.

53 A. Tovar, "Primitiva extensión geográfica del jonio», EMERITA 12, 1944, p. 288.

54 Sanmarti-Greco y Santiago, ZPE 68, 1987, p. 125, y "La lettre grecque...», RAN 21, 1988 , p. 15.

55 A. López Eire, Innovaciones del jónico-ático (vocalismo), Salamanca 1970, y «En busca de la situación dialectal del jónico-ático", Simposio Internacional de Colonizaciones, Barcelona 1974, p. 247 ss.; en general sobre estudios actuales de dialectología véase F. Rodríguez Adrados, Nuevos estudios de Lingüistica indoeropea, Madrid 1988, p. 429 ss., reuniendo trabajos anteriores. Cf. también A. López Eire, Symbolae Mitxelena, I. Vitoria 1985 , p. 81 ss.

56 Tovar, "Primitiva...», p. $286=I G$ XIV 759, 12 = Kaibel, Epiugr. gr. 1028, respectivamente.

57 Lejeune, «À propos...», p. 78. 


\section{Algunos topónimos}

Con el propósito de extender las tramas de investigación a otras áreas podemos hacer ciertas observaciones sobre toponimia griega del extremo Occidente.

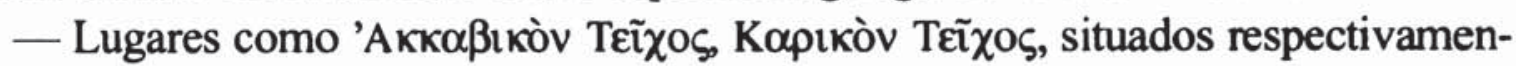
te en la zona de las Columnas de Hércules y Marruecos atlántico ${ }^{58}$, basadas en

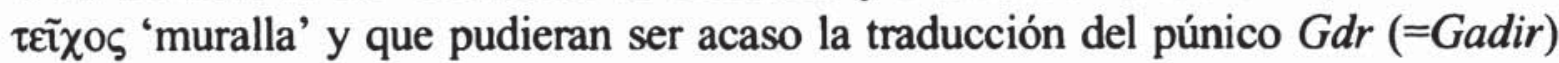
que significa esto precisamente, habrían podido elegir como modelo para la versión griega un topónimo de origen eolio, Néov Teĩ $0 \varsigma$ sitado por Heródoto como una de las doce ciudades de la confederación eólica ${ }^{59}$ que es la más antigua de las ciudades griegas denominadas mediante $ז \tilde{i} \chi 0 \varsigma \mathrm{y}$ algún adjetivo gentilicio o

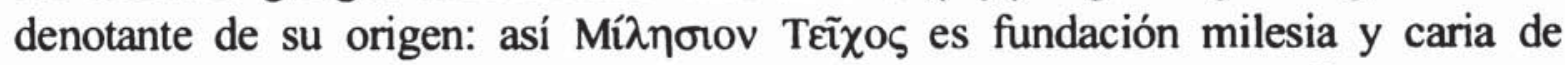

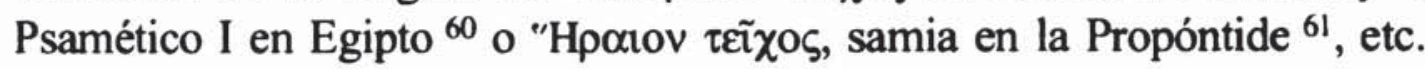

Otro topónimo que considerar es $\Sigma$ ıкuต́v ${ }^{62}$ lugar más allá de las Columnas de Hércules y que según su desinencia en Schulten daba como aquea ${ }^{63}$, lo que Tovar ${ }^{64}$ rechaza proponiendo su origen focense - como fundación-y recordando la coincidencia jonia y eolio-aquea en las formaciones en - $\omega v$. En la

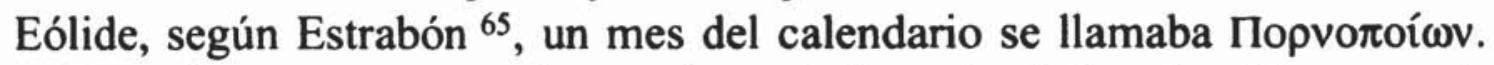

Estas formas tanto pueden registrar influencia dialectal eolia como jonia, pero en tanto que fundaciones o sencillamente fondeaderos comerciales, son evidentemente escalas focenses y a ellos deben su nombre, dado en el dialecto-puente de los focenses, que étnicamente, en sentido anfictiónico, interpolítico, decidieron ser jonios. No hay por qué acudir a una protocolonización caria, como propugnaba Schulten salvo por la cuestión del enigmático Kapıkòv $\tau \varepsilon \tilde{\chi} \chi 0 \zeta$ de Marruecos.

Están atestiguados otros varios topónimos griegos en la costa mediterránea del este español, pero de aspecto más jonio que éstos.

\section{El traslado de los foceos a Occidente}

El problema se plantea a la hora de evaluar el peso específico de estos eolismos en el habla focense $y$, en definitiva, considerar la importancia de lo eolio en la

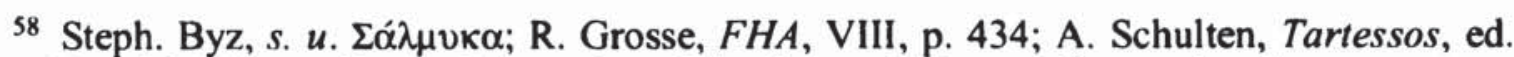
esp., Madrid 1971, p. 41 ss.; Grosse situa Salmyka en el Campus Spartarius sin argumentos.

${ }_{59}$ Hdt. I 149; Str. XIII 621; Plin. NH V 121; Steph. Byz., s. u.; J. Keil, RE XVI, 2431,

n. 2; G. E. Bean, Aegean Turkey, Londres, 1966, p. 98 ss.

${ }^{60}$ Str. XVII 1, 18.

${ }^{61}$ Hdt IV 90.

62 Plin. NH XXXVII 37.

63 Schulten, Tartessos, p. 46, n. 3.

64 Tovar, «Primitiva...», p. 302.

65 Str. XIII 613. 
formación de la Focea histórica. Para los editores del plomo de Ampurias, los eolismos de esta carta comercial pueden ser indicio de "arcaísmo" ${ }^{66}$ comparándola con la de Pech Maho, en el Languedoc, obra también de emporitanos, la cual no los presenta ${ }^{67}$. Es más, afirman estos autores que el redactor del texto es un individuo de la propia Focea y añaden que tal vez establecido en Massalia ${ }^{68}$.

Parece, pues, que se asocia estrechamente mayor arcaísmo con mayor grado de eolismo. Efectivamente, la carta de Ampurias es anterior a la de Pech Maho, en lo que convienen todos los autores. Piensa Santiago que por esta razón - se llevarían entre sí un máximo de tres cuartos de siglo- el documento languedociano ya no presentaba los eolismos, siendo puramente jónico: «ya no contiene arcaísmos eolios» ${ }^{69}$.

Esta argumentación, tras proponer mayor grado de eolismo a mayor arcaísmo, continúa con la localización del redactor como un foceo asiático. Esto es llevar el razonamiento seguido a las últimas consecuencias geográficas, pero este proceder tiene importantes implicaciones históricas, que no se ajustan demasiado bien a estas conclusiones, pues según nos informa Heródoto ${ }^{70}$ los foceos habían decidido evacuar totalmente la ciudad en 540 ante la amenaza médica, pero no todos pudieron mantenerse firmes en este propósito: así pues, una parte de ellos regresó a Focea y otra se dirigió a Elea en el Sur de Italia - y a otras colonias occidentales, evidentemente.

El epígrafe emporitano es posterior a estos acontecimientos, así como al enfrentamiento foceo contra los cartagineses en aguas de Alalía unos años después $(535 \text { a. C. })^{71}$. ¿No suponen estos eventos una suerte de hiato con aquellos otros focenses que se habían resignado a la sumisión ante los medos en su propia patria? Es decir, no hay ninguna necesidad metodológica de llevar el redactor de esta carta hallada en Emporion a Anatolia, sino más bien a Massalia o algún punto de la Magna Grecia. No parece en absoluto preciso hipotecar a una geografía anatólica la aparición de cada eolismo en el habla jónica del extremo occidente. El contingente foceo emigrado a Hesperia no debió quedar en buenas relaciones con los que habían roto su compromiso inicial y habían regresado a la Jonia.

Esta posición metodológica parece dar por supuesto que en cuanto los focenses venidos al Oeste abandonaron su posición de contacto con los eolios

66 Sanmartí-Greco y Santiago, «La lettre grecque...», p. 16.

67 Lejeune, Pouilloux y Solier, "Etrusque et ionien...», p. 36 ss.

68 Sanmarti-Greco y Santiago, "La lettre grecque...», p. 14 y «Empuries...», p. 6.

69 R. A. Santiago, «En torno a los nombres antiguos de Sagunto», Saguntum 23, 1990, p. 126.

70 Hdt. I 165.

71 Hdt. I 166. 
allá en su ciudad de origen, abandonaron paralelamente los eolismos de su habla. Pero ¿por qué razón? ¿Acaso por qué los epígrafes hallados hasta nuestras fechas eran un griego koiné, normalizado, de época helenística?

No. Tan teñida de eolismos es la lengua de la colonización focense como la de la propia metrópoli. Ya hemos reseñado otros eolismos tanto en el plomo grecoibérico de Sagunto como en ciertos topónimos. El desarrollo de un griego más koiné dependerá en Iberia, como en el resto de la ecumene helénica, de la cronología.

Por otra parte, la influencia focense sobre la aparición de la escritura grecoibérica a partir de la suya propia ${ }^{72}$ ha sido entre los iberistas algo más que una hipótesis ${ }^{73}$, ha sido un postulado del que ha pendido toda su labor acerca de la epigrafia grecoibérica.

Además, indirectamente esta consideración lleva a deducir a contrario que la población focense occidental, arribada aquí, no se olvide, también en pleno arcaísmo, fue evolucionando autónomamente durante el siglo $\mathrm{v}$ a un habla jónica expurgada de eolismos. Ello presenta graves dificultades metodológicas, pues los focenses occidentales por su geografia extremada respecto al meollo de la Hélade, quedaron bastante marginados de la evolución del mundo griego, no participando ni en las guerras médicas, ni en las peloponesíacas. ¿Cómo dar por supuesta esa rápida evolución en una población tan marginal, tan relativamente aislada? En realidad, a priori cabría considerar precisamente lo contrario: un mayor conservadurismo.

Entonces ¿cómo explicar la mayor pureza jónica del plomito de Pech Maho? Lejeune responde, sencillamente, que por puro azar. Los eolismos no figuraron en esta carta, de la misma forma que podrían haberlo hecho ${ }^{74}$.

Nuestro diagnóstico que localiza dos vocablos indígenas adaptados a la desinencia eólica en la antigua Sagunto no sólo es operativo cara a la determinante influencia de los focenses, sin duda los emporitanos, entre los iberos del Este peninsular, sino también lo es cara al estudio de los propios focenses. El hecho de que estos indígenas adaptasen esas dos palabras dos teónimos tal vez - para que sonasen a griego, precisamente con particularidades dialectales eólicas en la flexión de temas en $-a$ y $-o$, es una prueba palpable de que los eolismos no son algo esporádico en el habla focense $y$, posiblemente, tampoco un rasgo exclusivo del arcaísmo, sino de la época clásica, dada la cronología que proponemos. Si esta laminilla de plomo hubiese sido fruto de excavación metódica, tal vez los materiales acompañantes nos podrían haber proporcionado un espectro de datación

72 De Hoz, «La escritura greco-ibérica», p. 288.

73 Sanmartí-Greco y Santiago, "Une lettre grecque...», p. 16.

74 Lejeune, "La langue...» en "Etrusque et jonien archaique...», p. 52. 
para la misma. Pero no es así y en consecuencia, habremos de determinar su cronología exclusivamente por sus caracteres paleográficos. Ahora bien, éstos apuntan a un momento anterior al siglo IV, tanto por los paradigmas epigráficos focenses, como por la datación del plomo del Cigarralejo, indudablemente posterior, como hemos visto, a éste y que está bien fechado a mediados del siglo IV, tal vez algo posterior, según los materiales arqueológicos asociados al plomo, dentro de un "hallazgo cerrado» ${ }^{75}$. Los tipos del plomo de Sagunto son indudablemente más arcaicos, más fieles a su patrón focense y también más cuidados. Los paralelos paleográficos con la carta de Ampurias son abundantes y contribuyen a diferenciar aún más los tipos saguntinos de los de El Cigarralejo o La Serreta: A y $\Lambda$ simétricas, $Y$ sin tallo y $\mathrm{P}$ con y sin tallo. No faltan las concomitancias con la otra carta focense occidental, la de Pech Maho. A y $\Lambda$ simétricas. Y sin tallo, pero $P$ sistemáticamente con tallo en Pech Maho; en cambio aquí en Sagunto alterna, como en Ampurias. Recordemos que el de Pech Maho es de la segunda mitad del siglo $\mathrm{v}$, ¿puede servir esto para avejentar su datación? Es dudoso, pero en cualquier caso, téngase en cuenta que los otros plomos del sudeste presentan la rho sistemáticamente sin tallo, o apenas sin él, pareciendo en estos casos más bien una impericia en el último trazo del ductus del grafema que un tallo intencionado. El plomo saguntino en definitiva quedaría sin duda más próximo al momento de adaptación de la escritura grecoibérica ${ }^{76}$.

Sin embargo son esos mismos arcaísmos fosilizados que presenta la escritura grecoibérica del siglo IV, los que obligan a ser prudentes a la hora de datar este documento en un momento excesivamente antiguo.

En cualquier caso tenemos un hecho importante: bien en el siglo v, el del clasicismo heleno, bien en el IV, el habla focense emporitana mantenía los eolismos flexivos, superando cualquier cota reciente del arcaísmo.

El hecho de que figuren grafemas ibéricos en la primera línea del texto es posiblemente el mayor argumento para no datar con excesiva antigüedad este documento, que según las pruebas paleográficas expuestas resulta ser el más antiguo de los textos grecoibéricos de cierta extensión.

En fin, el mero hecho de haber redactado este documento saguntino en escritura griega - lo que nunca más se produjo, según el estado actual de conocimientos y eso que conocemos decenas de inscripciones ibéricas proce-

75 Cuadrado, «El plomo con inscripción ibérica...», p. 40 ss., 375/350 a. C. o segunda mitad del s. IV.

${ }^{76} \mathrm{De} \mathrm{Hoz}$, "La escritura...», p. 290 , pese a todo, a la hora de fechar el momento de adaptación del alfabeto jónico al ibérico, toma como guía esos arcaísmos, como los investigadores anteriores (v. supra). 
dentes de esta ciudad - puede ser un indicio de su antigüedad, pues conforme nos acercamos al siglo III la presencia cartaginesa en Iberia se hizo cada vez mayor, en relativo detrimento de los focenses.

Ahora bien, el horizonte del arcaísmo griego es la edad de oro de Focea y de sus colonias, tanto en el devenir histórico, como en la documentación escrita que sus ciudadanos elaboraron. Las referencias de Heródoto son casi coetáneas, las de Pausanias, retrospectivas: Focea como fenómeno histórico pertenece al arcaísmo. Existen, por supuesto, epígrafes posteriores al arcaísmo, incluso de época romana tanto en Massalia como en Emporion, pero no pueden parangonarse al conjunto de cartas arcaicas sobre plomo en longitud, ni en interés filológico.

\section{Otros influjos focenses revalorizados}

De parecida manera se ha procedido a revalorizar la influencia focense sobre las artes plásticas del arcaísmo ibérico. En este campo, la rehabilitación de la presencia focense ha sido de tal envergadura que la bibliografia acepta que el conjunto escultórico de Obulco (Porcuna) es un trabajo sencillamente focense $^{77}$. El cambio de actitud ha sido en verdad, pendular. Pero iera preciso el hallazgo de un importantísimo conjunto monumental como el de Porcuna, para poner sobre la mesa sin reticencias la decisiva influencia jónica sobre la plástica ibérica? Evidentemente no, a la vista de los trabajos de Niccolini acerca de la coroplastia ibérica contemporáneos de este período de silencio crítico de los estudiosos sobre la presencia focense en el Levante y Sur de España. Niccolini afirmaba sin tapujos que la coroplastia de varias piezas de estatuillas singulares de bronce del Cerro de Santos (Albacete) manifestaba unos modelos próximos en el arcaísmo griego, tanto en el modelado como en el tocado y la misma concepción de la pieza ${ }^{78}$. La escultura en piedra del Sudeste, a veces llamada «contestana», tiene también modelos griegos arcaicos, pero los hallazgos más importantes corresponden a Porcuna (antigua Obulco).

Sin embargo, lo más incomprensible del hipercriticismo antifocense es la existencia de la escritura grecoibérica, conocida desde 1922 en que Gómez

77 J. M. Blázquez y J. González Navarrete, "The Phokaian sculpture of Obulco in Southern Spain", American Journal of Archaeology 89, 1985, p. 61 ss.; I. Negueruela, Los monumentos escultóricos ibéricos del Cerrillo Blanco de Porcuna (Jaén), Madrid 1990. Antes de la aparición de este importante grupo escultórico, tan sólo Blanco Freijeiro, véase n. 4 , hizo recaer exclusivamente en los griegos el origen de la escultura mayor ibérica.

${ }^{78} \mathrm{G}$. Niccolini, «Quelques exemples de l'archaïsme grec sur la plastique ibérique», Actas V CEEC, Madrid, 1978, p. 809 ss. También M. Almagro Basch, «L'influence grecque sur le monde ibèrique", Actes du VIII congrès international d'Archéologie classique, París, 1965 , p. 92, de forma más general. 
Moreno publicó el plomo de Alcoy (Alicante) procedente del santuario ibérico de La Serreta, conocido como Serreta I entre los estudiosos españoles, pues allí aparecieron otros documentos en plomo, tanto en escritura ibérica, como grecoibérica ( $M L H$ G.1.1). Basta una ojeada al mapa para constatar la posición resueltamente meridional de Alcoy respecto a Emporion. $\mathrm{Y}$ más meridional todavía resulta el texto de El Cigarralejo de Mula (Murcia) también grecoibérico, descubierto un veintenio después.

En consecuencia, cualquier historiador o lingüista tenía a su disposición unos materiales intelectivos, unos documentos escritos que corroboraban espléndidamente ese impacto de la escritura jónica sobre los ibéricos. Semejante adaptación no tendría nada de particular, a la vista de textos lidios, galos, oscos, mesapios, vénetos, etc., escritos en sus respectivas lenguas bajo caracteres jónicos, si no fuese porque los iberos disponían, contemporáneamente a la redacción de estos textos aludidos - el de El Cigarralejo es del siglo IVde una escritura propia, que utilizaron en centenares de textos distribuidos por las regiones orientales de la Península Ibérica y que supusieron transmitir a sus vecinos celtas, los celtíberos.

Esta consideración proyecta un chorro de luz sobre la importancia de los griegos en el Sudeste, en la Contestania de época romana, que lamentablemente ha sido obscurecido por el hipercriticismo en boga hasta hace poco. La escritura grecoibérica quedaba sencillamente sin mención en el elenco de factores a considerar en el contacto grecoibérico. Como en otras cuestiones ideológicas predominaba un materismo de lo más burdo, que esperando encontrar restos ergológicos constructivos, urbanos, para formar un juicio favorable pues cerámicas griegas nunca han faltado ${ }^{79}$-, rechazaba paralelamente los materiales que documentan un contacto cultural, intelectual, espiritual.

Seguimos sin haber hallado colonias griegas en el Sudeste Hispano, pero contamos en estas consideraciones con nuevos textos grecoibéricos de reciente aparición: los grafitos de Campello, los de Benilloba, Baradellos y El Puig de Alcoy todos en la parte Norte de la provincia de Alicante, el plomo de Coimbra del Barranco Ancho, Jumilla (Murcia) y el presente plomo de Sagunto.

En línas generales, esta geografia de distribución de los hallazgos de escritura grecoibérica confirma su núcleo en la Contestania y una prolongación muy contigua en la Bastetania más oriental murciana, así como el hallazgo, aislado, de Sagunto.

Javier de Hoz ha estudiado recientemente la escritura grecoibérica, sistematizando sus signos. Los recientes hallazgos corroboran lo correcto de su aná-

${ }^{79}$ G. Trías, Cerámicas griegas de la Peninsula Ibérica, Valencia 1967; V. Page, Imitaciones de influjo griego en la cerámica ibérica de Valencia, Alicante y Murcia, Madrid 1984. 
lisis. Sin embargo hay que hacer algunas precisiones: no resulta metodológico, ni antes, ni después de los recientes hallazgos epigráficos ibéricos y grecoibéricos, proponer Samos en detrimento de Focea como origen de este alfabeto que viene a ser lo que ha entendido una parte de los investigadores por el hecho de que sea esta isla la que más documentos epigráficos del arcaísmo jónico haya conservado hasta la fecha ${ }^{80}$. Heródoto, Estrabón y otras fuentes más accidentales nos han legado el nombre de los colonizadores helénicos del Occidente: los focenses. El viaje de Koגaíos de Samos (infra) fue fortuito según Heródoto y sin establecimientos permanentes o mercados a plazo fijo. En cualquier caso la argumentación a favor de Focea no se hipotecaba al viaje del nauta samio.

De hecho, J. de Hoz presentaba la «tradición paleográfica documentable sólo en Samos - pero no conocemos las tradiciones propias a la mayoría de las ciudades jonias, entre ellas Focea - y que no ha podido adaptarse al ibérico con posterioridad a $c .450$ a. C.» ${ }^{81}$.

Si tanto se ha menospreciado el papel de los griegos en el Levante hispánico ¿cómo nunca se ha planteado la cuestión de la inexistencia de lengua ibérica escrita en caracteres fenopúnicos? Pues claro está, se consideraba a estos semitas como los intermediarios comerciales entre griegos e iberos, de forma casi exclusiva.

Evidentemente, corresponde a los griegos el haber transmitido a los iberos el uso del plomo como material escrituario ${ }^{82}$.

Sin embargo, el agnosticismo inicial hacia el vacío arqueológico de Focea era replanteado desde la búsqueda de paralelismos en la propia Jonia por Langlotz. En cuanto a la escultura se refiere el paralelo más estrecho es con Samos ${ }^{83}$. De Hoz se plantea si no será legítimo plantear el eventual paralelismo también en los estilos paleográficos ${ }^{84}$.

Las colonias focenses occidentales suministran los materiales que la propia Focea nos ha regateado ${ }^{85}$ y singularmente los epigráficos y lingüísticos en general ${ }^{86}$.

${ }^{80}$ H. Kyrieleis, Früher durch das Heraion von Samos, Atenas 1981.

81 J. de Hoz, «Las lenguas y la epigrafia prerromanas de la Península Ibérica», Actas VI CEEC, Madrid 1983, I, p. 365.

${ }_{82}$ J. de Hoz, «Escritura e influencia clásica en los pueblos prerromanos de la Península», $A$ Esp $A$ 52, 1979, p. 233 ss., y "La epigrafia focea vista desde el extremo Occidente», Actas VIII CEEC, Madrid 1989, III, p. 185.

${ }^{83}$ Langlotz, Die Kulturelle..., p. 43.

${ }^{84}$ Cf. n. 82 y J. de Hoz, "La escritura grecoibérica», Veleia 2-3, p. 289.

85 Langlotz, Die kulturelle..., pp. 19 y 31 ss.

${ }^{86}$ De Hoz, "La epigrafia focea vista...», p. 185 ss., y «La escritura grecoibérica», p. 290. 
Se ha dicho que «los objetos no son causa de aculturación, sino que su elección es consecuencia de la misma»" ${ }^{87}$. El nombre griego sólo quiere decir «que los griegos dan nombres comprensibles por ellos a divinidades extranjeras con las que, ellos creen, presentan las propias ciertas similitudes» ${ }^{88}$.

Pero iy si uno de los objetos escogidos resulta ser el sistema escriturario, precisamente el alfabeto? Diremos, ante todo, que este fenómeno no fue privativo de los iberos del sudeste, sino de muchos otros pueblos del Mediterráneo antiguo, como hemos dicho.

\section{Historia "étnica» de Focea. Etnia y dialecto}

Hace ya algún tiempo, en un trabajo sobre el dialecto jonio, Tovar sostenía la antigüedad y unidad interna del jónico-ático, anterior a su expresión literaria ${ }^{89}$ y en contraste con los demás dialectos. Sólo admitía como excepción precisamente la zona Norte de la Jonia asiática, al suponer que había sido primitivamente asiento de colonización eólica, pasando posteriormente al dominio de los jonios, citando concretamente los casos de Esmirna y Quíos ${ }^{90}$. En el primer caso según testimonio de Heródoto ${ }^{91}$, Mimnermo ${ }^{92}$ y Pausanias $93 \mathrm{y}$ en el caso quiota también según Pausanias ${ }^{94}$. Ni por un momento se cuestionaba el gran lingüista español si estos conceptos 'jonio', 'dorio', etc., eran verdaderamente lingüísticos en su acepción primitiva.

En cambio estas dos fuentes historiográficas troncales, Heródoto y Pausanias no dicen nada semejante referido a Focea, sino que atribuían la fundación de esta ciudad a un grupo de focidios de la Grecia centroseptentrional, de la región llamada Fócide. Es más, dejando la palabra a Pausanias:

Clazómenas y Focea no existian antes de la venida de los jonios a Asia... La mayoría de los clazomenios no eran jonios sino cleoneos y fliasios emigrados de sus ciudades cuando la invasión del Peloponeso por los dorios ${ }^{95}$.

Los de Focea proceden de la que aún se llama Fócide al pie del Parnaso y pasaron a Asia juntamente con los atenienses Filógenes y Damón, adquiriendo el país no por guerra, sino por un tratado con los de Cime. Los jonios no les admitieron en el

87 A. Domínguez Monedero, «Focea y sus colonias: a propósito de un reciente coloquio", Gerión 3, 1985, p. 365; en el aludido coloquio publicado en La Parola del Passato no se expusieron problemas epigráficos.

88 Ibid., p. 365-366.

89 Tovar, «Primitiva extensión geográfica...», p. 289.

90 Tovar, o. c., pp. 276-77.

91 Hdt. I 149.

92 Mimn. 12, 6 Diehl.

93 Paus. VII 5, $1 \mathrm{~s}$.

94 Paus. VII 4, 8.

95 Paus. VII 3, 8-9. 
Panjonion hasta que no tuvieron una dinastía de Códridas y por esto recibieron de Eritras y Teos a Deetes, Periclo y Abarto ${ }^{96}$.

Esta información de Pausanias no ha tenido la menor repercusión sobre los estudios de los focenses occidentales. No es cuestión de echarla al pozo sin fondo de las homofonías, pues Pausanias detalla los orígenes de cada una de las demás ciudades jonias, precisando sus peculiaridades: no tiene en principio nada a favor o en contra de la Fócide o Focea. Pero lo que queda fuera de duda es que para los escritores antiguos, Focea no fue fundación eolia pasada a jonia, sino focidia, que recibió después un barniz jónico entre otras cosas para poder entrar en la anfictionía y poder venerar oficialmente a Posidón Heliconio.

Los focidios no son mencionados en la historiografia clásica como eolios, a diferencia de sus vecinos tesalios y beocios. No hay sin embargo nada hasta la fecha en la epigrafia focense oriental u occidental que parezca focidio o griego del Noroeste: sólo jonio o eolio, en lo que se refiere a dialectos.

Tengo que aludir inevitablemente aunque sea de carambola al problema Focea/Fócide y el sustrato eolio. Es bien sabido que en dialectología griega se ha acudido a menudo al llamado sustrato eolio para explicar ciertos arcaísmos en el griego oriental, así como en el Peloponeso ${ }^{97}$. De la misma forma hay autores clásicos que consideran territorio eolio al de Tesprotia y Acarnania ${ }^{98}$. También parece claro que la Fócide, situada en un punto de contacto entre el eolio de Tesalia y Beocia y el griego del Noroeste en el que suele ser incluida, hubo de influir necesariamente, por mero contacto, en el eolio.

García Ramón ha tratado de aquilatar el verdadero peso del «sustrato eolio» ${ }^{99}$ en tanto que Rodríguez Adrados, con otros argumentos, duda del tal sustrato en inscripciones délficas y de la hipótesis de la existencia del mismo sustrato en la Fócide ${ }^{100}$.

Por tanto, en una situación en que no tenemos pruebas claras de ese eventual estrato eólico en Focidia, no cabe preguntarse si los rasgos eolios del dialecto focense hubiesen podido ser importados del continente. Tenemos que pensar como lo más seguro que el matiz eolio de Focea proceda del sustrato del propio país de asentamiento, la Jonia septentrional minorasiática, máxime cuando uno

96 Paus. VII 3, 10.

97 W. F. Wyatt, «Aeolic substrate in the Peloponnese», AJPh 94, 1973, p. 37 ss.

98 Thuc. III 102; Hdt. VII 176.

99 J. L. García Ramón, «El llamado sustrato eólico: revisión crítica», CFC 5, 1973, p. 233 ss., Les origines postmycéniennes du groupe dialectal éolien, Salamanca 1975, y Actas V CEEC, Madrid 1978, p. 99 ss.

${ }^{100}$ F. Rodríguez Adrados, La dialectología griega como fuente para el estudio de las migraciones indoeropeas en Grecia, Salamanca 1952, y Nuevos estudios de Lingüistica indoeruropea, Madrid, 1988, p. 473 ss. 


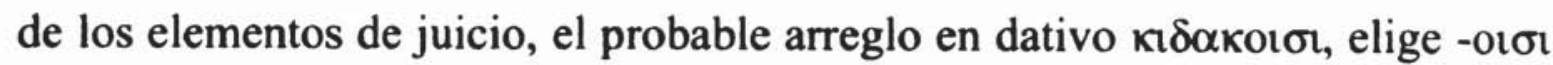
frente al eólico continental -oıc.

Hitzig y Blümner ${ }^{101}$ señalaban que en el pasaje de Pausanias acerca de la colonización de la Jonia había un núcleo histórico. Pausanias la presenta como una migración no sólo desde el Ática, sino también desde la Grecia central y el Peloponeso, dirigida, eso sí por los atenienses, por los hijos de Codro ${ }^{102}$ «los cuales no tenían nada de jonios en su estirpe, sino que eran mesenios de Pilos como descendientes de Codro y Melanto y atenienses por el lado materno"y.

Participaron también en la expedición de los jonios otros griegos: los tebanos que siguieron a Filotas, descendientes de Penebo, minias de Orcómeno por su parentesco con los hijos de Codro, focidios (excepto de Delfos) y abantes de Eubea. Dieron naves a los focidios los atenienses Filógenes y Damón, hijos de Euctemón, que fueron los jefes de este grupo. Cuando las naves arribaron a Asia, cada uno se dirigió a las diversas ciudades de la costa y Neileo y los suyos a la de Mileto» ${ }^{103}$.

El texto nos despeja la eventual tentación de considerar la mención de los focidios como una alusión al oráculo de Delfos o una intrusión interesada en la misma dirección. Nos ha sido transmitido hasta el detalle de la adquisición de sus navíos, pues los focidios no eran navegantes, no tenían acceso al mar. Curiosa paradoja fue que unas generaciones después, los de Focea se convirtieron en los más esforzados marinos griegos de la Antigüedad.

Pero hay otros nudos de interés, por ejemplo el hecho de que el territorio de Focea fuese adquirido mediante tratado de la vecina ciudad —eólica- de Cime y el fragmento de Nicolás Damasceno ${ }^{104}$ que menciona también «indígenas» - a los que hemos de identificar como eolios-, en el solar y vecindad de la futura Focea. Aquí tendríamos la respuesta. La documentación que estamos examinando nos permite reforzar esta explicación.

Heródoto no tenía duda alguna acerca de la diferenciación lingüística interna de los jonios, en un documento muy claro, lo que no le ha impedido ser rechazado de pleno por los defensores de la unidad dialectal original del jónico. Dice Heródoto:

Estos jonios a quienes pertenece el templo Panjonio han tenido la buena suerte de fundar sus ciudades bajo un cielo y en un clima que es el mejor de cuantos habitan los hombres, a lo menos los que nosotros conocemos... No hablan todos los jonios una misma lengua y puede decirse que tienen cuatro dialectos diferentes. Mileto, la primera

101 H. Hitzig y H. Blumner, Pausanias, Lipsiae 1904, II 2, pp. 762-763.

102 Paus. VII 2, 1-3.

103 Paus. VII 2, 2-4.

104 Nichol. Damasc. fr. 51 J 90. 
de sus ciudades, cae hacia el Mediodia y después siguen Miunte y Priene. Las tres están situadas en Caria y usan de la:misma lengua. En Lidia están Éfeso, Colofón, Lébedos, Teos, Clazómenas y Focea, las cuales hablan todas una misma lengua, diversa de la que usan las tres ciudades arriba mencionadas. Hay todavía tres ciudades de Jonia más, dos de ellas en las islas de Samos y Quíos y la otra, que es Eritrea fundada en el continente. Los quiotas y eritreos tienen el mismo dialecto, pero los samios usan otro particular suyo ${ }^{105}$.

Frente al testimonio de Heródoto, la posición habitual de la dialectología griega ha sido de un rechazo frontal, ejemplificado entre nosotros por Tovar, quien, pese a aceptar que la emigración jonia a Asia había partido no sólo del Ática, sino de Grecia central y el Peloponeso, sostenía que se trataba de una población homogénea lingüísticamente ${ }^{106}$.

También Clazómenas y Esmirna fueron originalmente ciudades eolias, como habría sido Focea; según Akurgal 107 al menos desde fines del siglo IX estos territorios estaban ya integrados en la confederación jonia. Nenci opina ${ }^{108}$ que fue el alumbre, que fue explotado intensamente hasta la Edad Media, lo que atrajo a los colonizadores. La tendencia jonia asiática a expandirse al septentrión pudo haber tenido este móvil económico. Según Ebner la fundación de la ciudad se haría con pleno conocimiento de las riquezas metalíferas de la zona ${ }^{109}$.

Sin embargo, lo que puede constatarse en cualquier autor es que los dialectos noroccidentales en el que debemos incluir el de la Fócide son clasificados, inventariados siempre más próximos al griego occidental y el dorio, que al eolio o al jonio (grupo oriental). Los focidios, que fundaron Focea, hemos de pensar, pues, que eran el conjunto de hablantes menos propiamente jónico de los colonizadores de la Jonia asiática y a su vez se asientan en un territorio cuyo sustrato $\mathrm{y} / \mathrm{o}$ vecindad es eolio.

Pero ya asentados en Anatolia, los focidios, convertidos ya en focenses, deciden integrarse interpolíticamente en la Jonia confederada. En consecuencia, ha sido el proceso de emigración, con la recluta de armadores y pilotos, la organización del traslado masivo, el factor que ha pesado más a la hora de definir su ¿qué? Su anfictionía antes que nada, su culto en común a Posidón Heliconio y, además, según sabemos nuevamente por la documentación occi-

105 Hdt. I 142.

106 Tovar, «Primitiva extensión geográfica...», p. 292.

107 E. Akurgal, "The Early Period and the golden Age of Ionia», American Journal of Archaeology 66, 1962, p. 370.

108 G. Nenci, "L'allume di Focea», en I Focei dell'Anatolia al Oceano, La Parola del Passato (PP) 204-207, 1982, p. 183 ss.

109 F. Sartoux, «Recherches sur le site de l'ancienne Phocée», GRAI, 1914, p. 6 ss.; P. Ebner, "Il mercato dei metalli preciosi nel secolo d'oro dei Focei (630-545 a. C.)", PP 21, 1966 , p. 111 ss. 
dental focense (102), también el culto a Ártemis efesia. Este factor pesa más en su conciencia "poliada" que el sustrato eolio que opera en el territorio de asentamiento, más que las buenas relaciones documentadas con Cime, la polis eolia que había cedido amistosamente el terreno, por tratado. Los focenses o foceos, sin renunciar a su gentilio específico y ahora poliada quisieron ingresar en la comunidad jonia y lo hicieron mediante un mecanismo, en definitiva, religioso.

Otros paralelismo indudable de Focea con la Eólida es la cerámica gris arcaica de la zona, la misma que los arqueólogos españoles y franceses localizan en los yacimientos occidentales y denominan "gris focense» o "gris emporitana». Concretamente Villard comparaba la cerámica "gris masaliota" con las producciones arcaicas de la isla de Lesbos, grisáceas y monocromas unas y otras ${ }^{110}$. La cerámica jónica más típica del arcaísmo, la milesia o samia por ejemplo, son diferentes. Debemos aceptar, pues, que tampoco definen el ع̌ $\theta v o \zeta$, los elementos ergológicos comunes, lo cual afortunadamente no ha sido casi nunca un criterio determinante en los estudios étnicos griegos, aunque desgraciadamente sí, y mucho, en los paleohispánicos.

Hainsworth 111 explica el origen de la división tradicional de los dialectos griegos por los autores clásicos como «una mezcolanza de la actitud respecto al dialecto de tres disciplinas diferentes: la etnografia, la glosografía y la exégesis literaria», lo que es cierto, pero se olvida de lo principal, de la genealogía, del hecho de sentirse, de saberse descendiente de tal o cual personaje mítico, al margen del grado de veracidad que concediesen al mito en sí mismo: es evidente que todos los dorios pensaban que tenían unos antepasados comunes vinculados estrechamente a Hércules, en un grado que ni jonios, ni eolios poseían.

En buena parte, la investigación ha pretendido contestar a cuestiones dialectológicas con proposiciones encabezadas por conceptos genéricos o étnicos

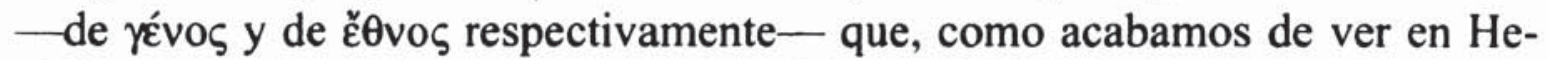
ródoto, para los griegos no eran ni políticos, ni lingüísticos. Partimos de la insuficiencia del vocabulario de las lenguas modernas para designar cuestiones de parentesco y estirpe y además, despreciamos la importancia que estos asuntos tenían en las sociedades antiguas para organizarse internamente y en relación a sus vecinos. Para Heródoto los griegos eran una etnia - palabra recu-

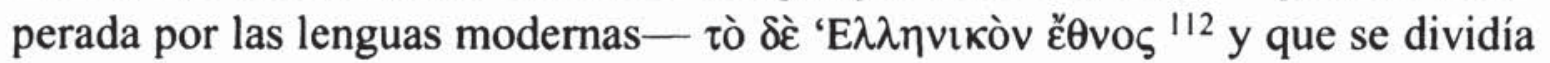
en géneros, en gentes, así el yévoৎ de los dorios, o el de los jonios. Nada de dialectos, de ergología, ni siquiera de religión o anfictionía: de linaje. Desde

110 F. Villard, La céramique grecque de Marseille, París 1960 p. 51 ss.

III J. B. Hainsworth, "Greek views of Greek Dialedctology», TPhS, 1967, p. 62 s.

112 Hdt. I 56. 
luego no se priva de establecer en un texto muy traído y llevado la relación entre los epónimos dorios y los espacios geográficos ocupados por cada una de sus estirpes, de parecida forma a como el pseudo Hesíodo establecía la relación entre dorios, jonios y eolios que serían los descendientes de los tres

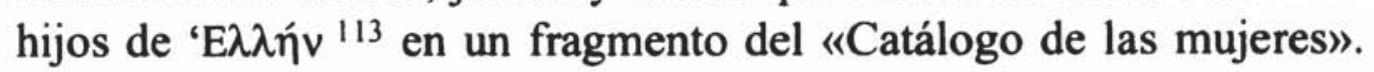

En el caso de Focea es evidente que su inclusión en el Yévos jonio se hizo por agregación, forma que las sociedades antiguas estimaban perfectamente válida para ampliar la estirpe. El factor religioso era el único capaz de romper la barrera de la distinta procedencia étnica, por encima de criterios como el lingüístico o el de vecindad en el punto de partida. Sólo se dio el preequisito de aceptar jefes jonios en el montaje de la migración, por lo demás estrictamente necesarios como navegantes transportistas.

Platón estimaba que las fundaciones coloniales mixtas presentaban más pro-

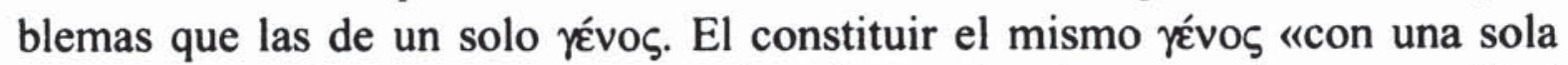
lengua y una sola ley comporta una cierta benevolencia, ya que hay comunidad de cultos y de todas las demás cosas de este tipo...» En cambio en las fundaciones mixtas al constituir una sola nueva unidad «quizá se preste a acatar ciertas leyes nuevas, pero en cuanto a tener todos el mismo espíritu... es cosa de mucho tiempo y máxima dificultad» ${ }^{114}$. Indudablemente aquí Platón opera con un tipo de metrópolis ideal, con una uniformidad total en su seno. También

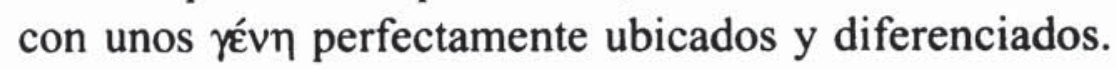

El factor lingüístico (dialectal, más propiamente) es uno de los que pueden conducir a la comunidad de cultos, un factor que sigue al linaje en la consideración del deseable futuro bienestar de la polis. El texto platónico evidencia la importancia del dialecto en época clásica, pero también del linaje en orden a lograr un mismo espíritu para todos los ciudadanos y es prueba, desde luego, de que en el siglo IV continuaban las diferencias dialectales dentro de algunas ciudades fruto de la colonización.

La tendencia actual en dialectología es puramente lingüística y sólo se apoya en consideraciones historiográficas acerca de las ramas del pueblo griego cuando concuerdan con los materiales lingüísticos. Una posibilidad de caracterizar el dialecto foceo sería el de dialecto puente.

El caso de los orígenes étnicos de Focea es de los más complejos de la colonización griega y tal vez, extremo: focidios acaudillados por jonios que se instalan sobre un sustrato eolio y que posteriormente emprenden a su vez una colonización. Ya hemos visto que hubieron de renunciar a sus cultos previos para unirse al de Posidón Heliconio. Entonces pudieron romper con su pasado

${ }^{113}$ Hesíodo, Catal fr. 4 (Evelyn-White): Plut. Mor. 747; schol. Pind. Pyth. IV, 263.

114 Plat. Leg. 708 b-d. 
focidio para convertirse en jonios: es evidente que nos les exigieron cambiar de dialecto para ello y este punto queda bien demostrado en la descripción, ya vista, de Heródoto. No era fácil en el mundo antiguo desprenderse de un linaje estricto que operaba filogenéticamente, de forma mecánicamente biológica y parental a través de siglos y siglos. En nuestro tiempo no se suele dar importancia a este aspecto de la vida social y familiar, pero sí en toda la Antigüedad y también entre los griegos. Hoy, podemos encontrar esta mentalidad en ciertas comunidades como la judía: el rubio hebreo de Vilna, de lengua yiddish y ascendencia ashkenazi tiene perfecta conciencia de descender de Abraham y Sara, de la misma forma que es hijo de sus padres que figuran en el registro civil, sólo que separado por unos millarcillos de años. Pero el judío etíope, el falasha, negro y de lengua ge'ez o cushita, se considera a su vez tan descendiente de Abraham como el anterior. Si esto ocurre hoy día, no se nos oculta que sólo una creencia religiosa permite tener conciencia de esa descendencia biológica (sea real o no, lo que es indiferente). Pero calcúlese en sociedades más cerradas de la Antigüedad, lo importante que podía resultar en determinado momento ser eolio o dorio en cuestiones de linaje estricto. El dialecto no

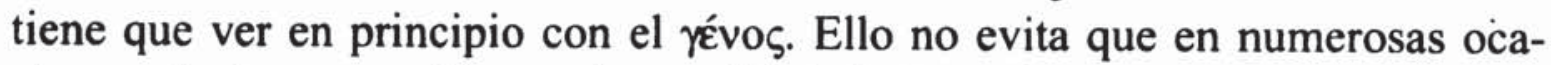
siones el yévos se aplique a la totalidad de los griegos u otros pueblos por numerosos escritores, pero este espectro semántico no resultaba equívoco en cada situación determinada.

Cabe suponer, pues, que en el seno de las comunidades focenses occidentales (y singularmente Emporion) unas familias mantuvieron la impronta eólica en su sermo familiaris y por lo que sabemos, fueron algunas de esas las que se ocuparon de comerciar con los iberos de la actual España. En cambio, a juzgar por el plomo de Pech Maho, los emporitanos que comerciaban con este punto del Languedoc, usaban de un dialecto más puramente jonio. Es de suponer que la propia política comercial de las autoridades emporitanas favorecería el mantenimiento de una misma «lingua franca» y consiguientemente, de ciertas mismas familias concretas de comerciantes en el trato con una misma comunidad indígena del litoral. Aunque los indígenas tenían sin duda intérpretes, como los foceos, no podía correrse el riesgo de ir alterando las fórmulas fonéticas de trato comercial, máxime si se habían suscrito pactos por escrito. Estamos, pues, ante un contrato que comienza con unos onomásticos iteónimos, gentilicios? acordados al habla griega con la que los iberos estaban familiarizados y que pudiese ser inmediatamente reconocible para los comerciantes foceos.

En consecuencia, hemos de admitir que la toponomástica ibérica se vio afectada en el litoral Mediterráneo, por la acción focense: así cobran sentido topónimos arreglados a estilo minorasiático a partir de las lenguas paleohispá- 
nicas como Onus(s) a o Lebedontia, la cerámica gris focense, o las desinencias amañadas a lo eólico en el plomo saguntino, que no pudiendo ser del siglo $\mathrm{VI}$ por cuanto sabemos de la escritura ibérica, ha de ser posterior: es decir, que los rasgos eólicos se mantienen después del período del arcaísmo griego entre los emporitanos, pero no entre todos ellos; aquellos otros que redactaron el plomo de Pech Maho, escribían en dialecto jónico y anotaban su propio gentilicio con pi simple, no germinada: hasta ahí llegaban las diferencias en el seno de la comunidad focense emporitana, que siendo tan minúscula como emprendedora, mantenía matices dialectales diferentes entre sus ciudadanos.

Hace poco Domínguez Monedero se preguntaba si sería posible una identificación de los focenses que abandonaron Alalia tras la famosa naumaquia de $535^{115}$ contra etruscos y púnicos. Y proponía en consecuencia que los que permanecerían en Alalia serían los naturales de la ciudad y los que se marcharon serían los que recientemente habían venido de Focea o una parte de ellos ${ }^{116}$, huyendo de la amenaza persa. Esta nueva migración les llevó a Elea (o Hyele) en un lugar previamente frecuentado y tal vez por concesión de Posidonia ${ }^{117}$.

Tal vez una parte de los que decidieron abandonar Alalia marchasen a las colonias del Extremo Occidente.

\section{Luciano Pérez Vilatela}

115 Hdt. I 166.

116 A. Domínguez Monedero, «Focea y sus colonias...», p. 375.

117 J. Jehasse, "La "victoire à la cadméenne" d'Hérodote $(1$ 166) et la Corse dans les courants d'expansion grecques», $R E A 64,1962$, p. 274 ss.; E. Lepore, "Elea e l'eredità di Sibari", $P P 21,1966$, p. 258 ss. 


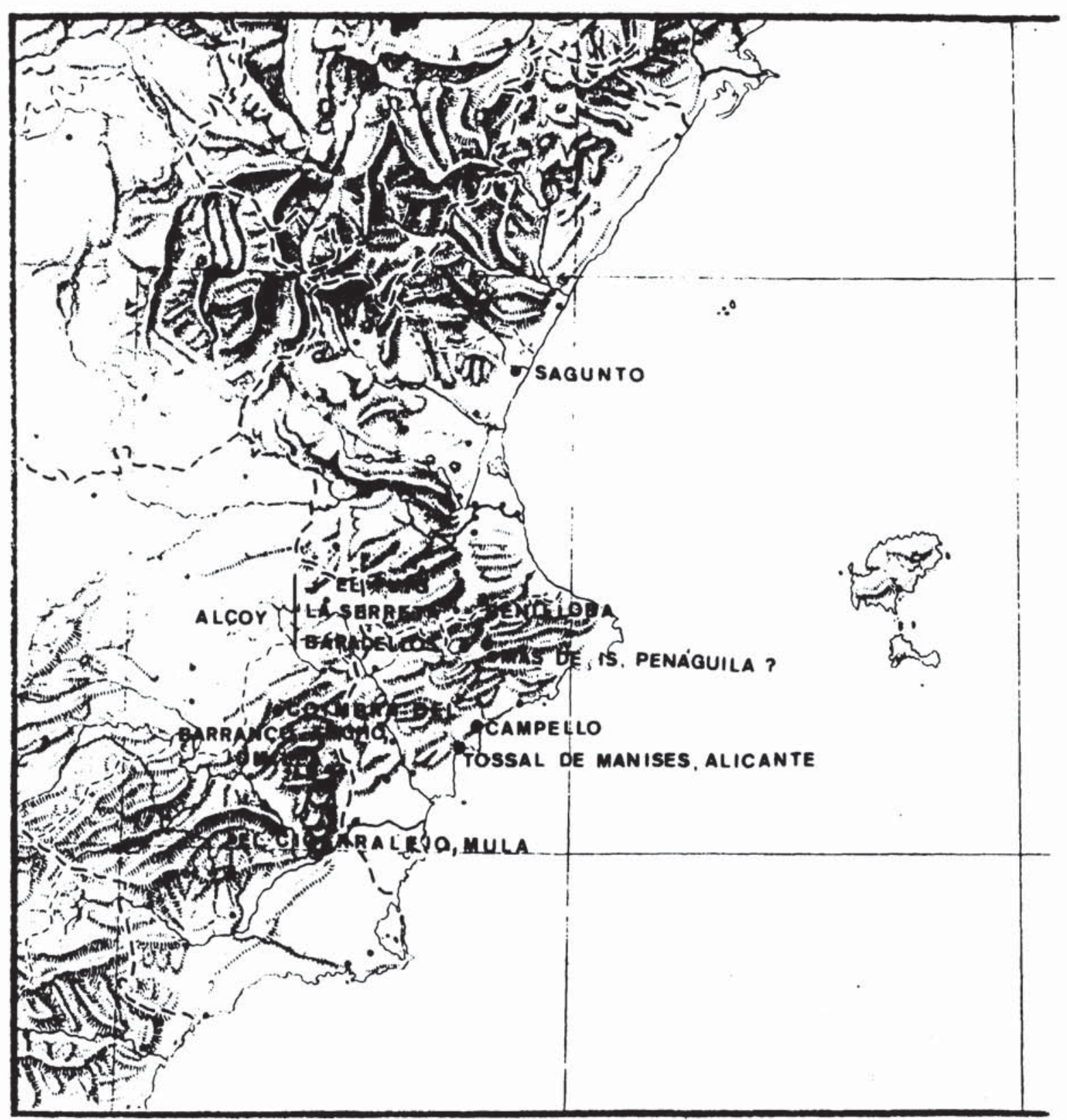

FIGURA 2: Distribución geográfica de la escritura grecoibérica. 
1

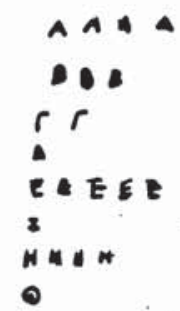

111

$K \kappa \times K$

4

$m m$

ham

$\vdots$

000000

$p$

APPPPPP

ises

THT

$v \vee v$

$+$

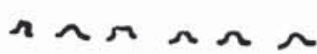

2

คดคคล ค

$B$ B

$\Gamma$

$\triangle A \triangle \triangle$

EEEEEE E

$t$

H H H H

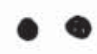

111

KKKkKk

$1 n$

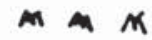

$\sin n \pi$

I

$000000<$

$n \cos$

$P P P$

$<<<\leqslant \leqslant<1$

$T T T$

VYrV

$+t+$

$n \cap \Omega \Omega$
3

4

A A

A A A AAA

10

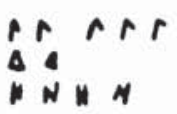

111

KKKKK

Aก

$n$

000

r r ror

\{

$r t$

$\checkmark \vee r v$ $r$

o

H H K

I I

* K $k$

$n$

N

$\Delta x$

00

₹3

$v x$

m $m \mathrm{~m}$

$\bar{x} \bar{x} \times \bar{x} x$

$<<$

FiguRA 3: Comparación paleográfica entre alfabetos griegos focenses occidentales y alfabetos grecoibéricos. Diversas escalas.

1. Carta n. I de Ampurias.

2. Plomo emporitano de Pech Maho (Aude, Languedoc).

3. Plomo grecoibérico de Sagunto.

4. Plomo grecoibérico de Coimbra del Barranco Ancho (Jumilla, Murcia).

En este último, como en el del Cigarralejo (Mula), etc., se acentúan los trazos cursivos y abiertos. En cambio, en el de Sagunto la fidelidad a los paradigmas focenses es ejemplar.

Escala: 1-3, a su tamaño, aproximadamente; n. 4 ampliado un tercio. 